\title{
Pemberdayaan Warga Kelurahan Klandasan Ilir, Balikpapan, dalam Pengelolaan Lingkungan dan Minyak Jelantah
}

\author{
Siska Ayu Kartika*1, Muhammad Dani' ${ }^{2}$, Ardi Suherman ${ }^{3}$ \\ Fahmi Toriq ${ }^{4}$, Putra Pranata ${ }^{5}$ \\ 1,2,3,4,5Program Studi Teknik Mesin, Fakultas Teknologi Industri, Universitas Balikpapan \\ *e-mail: siska.ayukartika@uniba-bpn,.ac.id ${ }^{1}$, danimuhammad2694@gmail.com², \\ ardisuherman.mech@gmail.com ${ }^{3}$
}

\begin{abstract}
Environmental management, especially in this case regarding cleanliness and waste management issues must be a common concern. Community participation must be involved to increase a sense of concern for a clean and healthy environment. This Community Service Activity (PKM) was carried out in Klandasan Ilir, Balikpapan due to several problems related to the lack of awareness and understanding of the community in issues of environmental management, and how to manage household used cooking oil. The method of activities carried out is by identifying the existing problems, generate planning activity programs according to the residents' needs and time, as well as implementing and evaluating the activities carried out. As a result, the residents of Klandasan Ilir have a new understanding of the importance of environmental management and managing used cooking oil that is good for the environment and health, as well as increasing awareness of the importance of cleanliness and preservation of the surrounding environment.
\end{abstract}

Keywords: awareness, environmental management, cleanliness, used cooking oil

\begin{abstract}
Abstrak
Pengelolaan lingkungan, terutama dalam hal ini mengenai masalah kebersihan, pengelolaan sampah dan penghijauan harus menjadi perhatian bersama. Partisipasi masyrakat harus terus ditumbuhkan untuk meningkatkan rasa kepedulian terhadap lingkungan yang bersih dan sehat. Kegiatan Pengabdian Kepada Masyrakat (PKM) ini dilakukan di Kelurahan Klandasan Ilir, yang berada ditengah kota Balikpapan karena adanya beberapa masalah terkait kurangnya kesadaran dan pemahaman masyarakat dalam masalah sanitasi, kebersihan dan pengelolaan lingkungan, termasuk penghijauan, dan bagaimana mengelola minyak jelantah rumah tangga yang dihasilkan setiap hari. Metode kegiatan yang dilakukan adalah dengan melakukan identifikasi permasalahan yang ada diwarga kelurahan, merencanakan program kegiatan yang sesuai dengan kebutuhan dan waktu warga, serta melaksanakan dan mengevaluasi kegiatan yang dilakukan. Hasil dari kegiatan PKM ini, warga Kelurahan Klandasan Ilir memiliki pemahaman baru mengenai pentingnya pengelolaan lingkungan, cara dan metode penanaman pohon disekitar hunian, pengelolaan minyak jelantah yang baik bagi lingkungan dan kesehatan, serta bertambahnya kesadaran akan pentingnya kebersihan dan kelestarian lingkungan sekitar.
\end{abstract}

Kata kunci: kesadaran masyarakat, pengelolaan lingkungan, kebersihan, minyak jelantah

\section{PENDAHULUAN}

Permasalahan pengelolaan sampah, terutama dalam hal ini sampah rumah tangga selalu menjadi isu utama dalam masyarakat (Siswati et al., 2020). Seiring meningkatnya jumlah penduduk di suatu daerah maka akan mengakibatkan ikut bertambahnya volume sampah. Pola konsumsi dan gaya hidup masyarakat ikut memberikan kontribusi dalam meningkatnya jumlah sampah yang semakin beragam jenisnya. Sampah rumah tangga merupakan salah satu sumber peningkatan volume sampah di suatu lingkungan (Sari, Lestari, \& Awal, 2018). Salah satu upaya yang dapat dilakukan untuk mengatasi permasalahan sampah domestik di Indonesia adalah dengan melakukan perubahan gaya hidup masyarakat. Gaya hidup yang diusung sebagai upaya mengatasi masalah sampah adalah gaya hidup positif yang minim sampah (zero waste), yaitu meminimalkan penggunaan bahan yang mencemari lingkungan dan menolak pemakaian bahan sekali pakai. Tujuannya adalah meminimalisir jumlah sampah yang dikirim ke TPA (Mayangsari, Nurhayati, Junaenah, \& Kurniasih, 2020). Penanganan sampah permukiman, selain peran pemerintah sebagai fasilitator, juga memerlukan partisipasi aktif baik individu maupun kelompok masyarakat (Sukib, Muti'ah, Siahaan, \& Supriadi, 2020). 
Sampah plastik juga merupakan salah satu jenis sampah yang banyak dihasilkan dari kegiatan rumah tangga. Sampah plastik, merupakan jenis sampah yang sulit terurai, sehingga dapat merusak ekosistem secara masif, karena daya hancurnya terhadap lingkungan begitu besar (Greenpeace Indonesia, 2019). Kurangnya kesadaran masyarakat untuk membuang sampah pada tempatnya, dan menjaga kebersihan lingkungan masih terus harus selalu disosialisasikan ke masyarakat. Kegiatan sosialisasi kepada masyarakat dan aksi bersih pantai harus selalu digalakkan, agar masyarakat, terutama yang tinggal didaerah pesisir pantai, dapat ikut dilibatkan dan menumbuhkan kebiasaan baik masyarakat yang dilakukan untuk menjaga kebersihan.

Selain itu, salah satu upaya yang diharapkan dapat mendukung kebersihan pesisir adalah adanya upaya proaktif dari elemen masyarakat, dalam hal ini adalah para penduduk lokal yang tinggal disekitar pesisir pantai. Beberapa referensi menyarankan agar dilakukan upaya kerja bakti secara rutin untuk membersihkan pantai sebagai salah satu langkah yang dapat diambil untuk menjaga kelestarian lingkungan pesisir (Izza M Apriliani, Noir P Purba, Lantun P Dewanti, Heti Herawati, 2017). Kurangnya kepedulian terhadap lingkungan, dapat disebabkan oleh kurangnya pengetahuan masyarakat dalam melestarikan lingkungan ataupun karena sikap mereka yang memang tidak ada kemauan dalam dirinya untuk melestarikan lingkungan sehingga kurangnya tindakan dari masyarakat tersebut (Hidayat, 2017).

Selain sampah plastik, minyak sisa hasil dari kegiatan penggorengan, atau yang biasa kita kenal sebagai minyak jelantah, juga perlu untuk mendapat perhatian khusus. Minyak jelantah berasal dari penggunaan minyak goreng berulang kali yang dapat berasal dari minyak jagung, minyak kelapa sawit, dan sebagainya (Kataren, 2005). Kerusakan minyak goreng dapat dilihat dari tanda awal berupa terbentuknya akrolein pada minyak goreng. Pada saat mengkonsumsi makanan yang digoreng menggunakan minyak goreng berulang kali, akrolein ini menyebabkan rasa gatal pada tenggorokan. Selain itu, menurut hasil penelitian (Rukmini, 2007) mengkonsumsi minyak jelantah secara berkepanjangan dapat mengakibatkan kerusakan pada organ tubuh seperti, kerusakan pada liver (sel hepar), jantung, pembuluh darah maupun ginjal (Vamala, Akbar, Widayanti, Lingkungan, \& Jelantah, 2019). Minyak goreng bekas pakai juga merupakan salah satu jenis sampah rumah tangga yang memiliki dampak yang cukup berbahaya pada lingkungan bila tidak terkelola dengan baik, misalnya jika dibuang pada pembuangan air akan menyebabkan penyumbatan pipa.

Permasalahan utama yang harus diperbaiki adalah mengenai minimnya pengetahuan masyarakat terhadap minyak goreng bekas pakai dan bahayanya bila tidak dikelola dengan baik. Kenyataannya dilapangan, kita melihat ada beberapa pengepul yang hanya dengan sekali menyaring minyak goreng bekas pakai tersebut kemudian langsung diperjualbelikan ke masyarakat. Minyak goreng bekas pakai yang dijual kembali itu disebut sebagai minyak goreng residu. Pada masyarakat ekonomi rendah, mereka sering menggunakan minyak goreng residu yang dijual kembali dengan harga yaitu Rp 6000/liter, sebagai alternatif untuk menggoreng atau mengolah makanan, lebih murah dibandingkan minyak goreng kelapa sawit. Sehingga diperlukan sosialisasi kepada masyarakat mengenai dampak pemakaian minyak goreng bekas pakai bagi kesehatan, karena mengandung asam lemak yang tinggi yang akan menjadi zat karsinogenik yang dapat meningkatkan risiko terkena kanker (Linarti, Astuti, \& Budiarti, 2019).

Secara teoritis, minyak goreng bekas pakai sebenarnya dapat dikelola menjadi sumber nilai yang memberikan banyak manfaat, diantaranya dapat diolah kembali untuk menjadi bahan bakar alternatif, sabun, karbol, minyak aromaterapi, dan biodiesel. Oleh karena itu perlu juga dilakukan kegiatan sosialisasi kepada masyarakat yang bertujuan untuk meningkatkan pengetahuan mengenai bahan kimia dalam rangka meningkatkan upaya pemeliharaan kualitas lingkungan hidup di sekitar rumah tangga (Simanjuntak, Sanga, Purba, \& Irawati, 2019).

Bentuk pengelolaan lingkungan yang lain adalah melakukan kegiatan penghijauan, dengan penanaman pohon dan memberikan pengetahuan serta pemahaman kepada masyarakat mengenai pentingnya melestarikan lingkungan (Pratiwi, 2017). Kegiatan ini juga salah satu bentuk untuk menjaga lingkungan agar selalu terlihat asri, sejuk dan nyaman untuk dihuni. 
Kegiatan penanaman yang dilakukan masyarakat perlu diberikan pendampingan dikarenakan tidak semua masyarakat memiliki keterampilan untuk menanam pohon terutama apabila tanaman yang ditanam mengalami kendala seperti kekurangan unsur hara, terkena serangan hama dan penyakit. Kegiatan pendampingan tidak hanya memberikan masukan teori, tetapi juga menampung kreativitas masyarakat yang secara tidak langsung dapat digunakan sebagai bahan untuk kajian pengembangan untuk mengatasi masalah yang umum dihadapi oleh masyarakat (Harisman, Frasetya, Sudrajat, Birnadi, \& Sholeha, 2019)

Masyarakat harus mengerti dan mau berpartisipasi bila perlu juga berubah sikap dalam upaya pengelolaan lingkungan, mulai dari pengurangan volume sampah, perbaikan kualitas sampah, sampai pada penyediaan lahan, dan pemusnahan sampah. Oleh karena itu diperlukan upaya dan usaha yang terus menerus kepada masyarakat untuk peduli terhadap lingkungan. Pemberian penghargaan untuk upaya kepedulian juga merupakan salah satu langkah memberikan motivasi kepada masyarakat (Suryani, Aje, \& Tute, 2019). Masyarakat senantiasa akan ikut bepartisipasi terhadap proses pembangunan bila terdapat faktor-faktor yang mendukung, antara lain: kebutuhan, harapan, motivasi, ganjaran, kebutuhan sarana dan prasarana, dorongan moral, dan adanya kelembagaan baik informal maupun formal (Dan et al., 2020).

Alasan pemilihan Kelurahan Klandasan Ilir, Balikpapan, Kalimantan Timur sebagai tempat pelaksanaan kegiatan PKM ini, karena berdasarkan pertimbangan lokasi Kelurahan Klandasan Ilir berada ditengah kota dan sesuai dengan maksud dan tujuan dari PKM ini. Beberapa masalah yang diidentifikasi di Kelurahan Klandasan Ilir adalah sebagai berikut: a) Kurangnya kesadaran masyarakat dalam masalah sanitasi, kebersihan dan pengelolaan lingkungan, termasuk penghijauan, b) Masih diperlukannya kegoatan soslaisasi berupa pembekalan materi kepada masyarakat mengenai pengelolaan minyak jelantah rumah tangga. Adapun tujuan yang hendak dicapai dari program pengabdian masyarakat ini, adalah untuk memberikan pemahaman kepada masyarakat mengenai cara mengatasi masalah sanitasi dan pengelolaan lingkungan dan bagaimana pengelolaan minyak jelantah yang dihasilkan warga setiap harinya. Sehingga diharapkan warga dapat mengimplementasikanya dalam kehidupan sehari-hari dan menjaga kelestarian lingkungan sekitar dengan bentuk pengelolaan lingkungan yang baik.

Kelurahan Klandasan Ilir merupakan bagian dari wilayah Kecamatan Balikpapan kota dengan luas daerah sebesar 2.430,10 Ha. Kelurahan klandasan Ilir terdiri dari 62 RT (Rukun Tetangga) dengan jumlah kepala keluarga sebesar 7.906 kepala keluarga dan 28.766 jiwa, sesuai data yang dihimpun dari Kelurahan Klandasan Ilir pada tahun 2017. Rencana program kegiatan yang dapat dilakukan di Kelurahan Klandasan Ilir untuk kegiatan PKM ini diantaranya adalah: a) Pelaksanaan penanaman/penghijauan di kawasan Kelurahan Klandasan Ilir dengan mengajak partisipasi warga di RT setempat. Hal ini bertujuan untuk menciptakan Kawasan Kelurahan Klandasan Ilir menjadi lebih asri, sesuai kesepakatan dengan Lembaga Pengabdian Masyarakat (LPM) Kelurahan Klandasan Ilir; b) Pelaksanaan kerja bakti bersama warga di daerah Kelurahan Klandasan Ilir khususnya kawasan pesisir pantai (RT 32, RT 36, RT 50). Hal ini dilakukan untuk meningkatkan kesadaran masyarakat akan pentingnya kebersihan, terutama bagi mereka yang tinggal dikawasan pesisir pantai; c) Pelaksanaan sosialisasi penanganan minyak jelantah rumah tangga, untuk memberikan pemahaman kepada warga bagaimana penanganan minyak jelantah yang jika tidak dikelola dengan baik akan berdampak bagi lingkungan.

Tabel 1. Hasil identifikasi masalah di beberapa lokasi RT, Kelurahan Klandasan Ilir

\begin{tabular}{llll}
\hline No & Permasalahan & Lokasi (RT) \\
\hline 1 & $\begin{array}{l}\text { Masih kurangnya kesadaran warga akan } \\
\text { kebersihan lingkungan }\end{array}$ & \\
2 & $\begin{array}{l}\text { Pencemaran pantai, karena banyaknya sampah } \\
\text { disekitar pesisir pantai }\end{array}$ & 32,36 \\
3 & Lingkungan kurang asri & $19,18,22,21$ \\
\hline
\end{tabular}




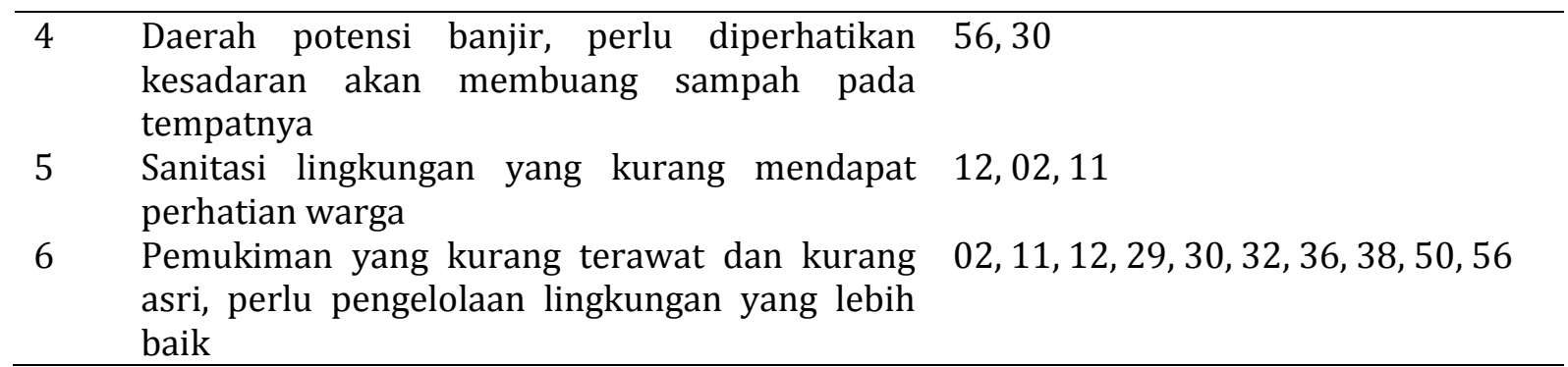

Identifikasi masalah pada tabel 1 diperoleh melalui pengamatan yang telah dilakukan di kawasan Kelurahan Klandasan Ilir, dan dengan melakukan kunjungan ke beberapa RT setempat serta melakukan wawancara kepada masing-masing ketua RT. Setelah itu dilakukan pemilihan prioritas masalah yang paling utama dilakukan dengan cara diskusi, sehingga didapatkan prioritas pemilihan masalah seperti terlihat pada tabel 2 .

\section{METODE}

Kegiatan Pengabdian Kepada Masyarakat (PKM) merupakan wadah bagi dosen dan mahasiswa dalam menerapkan dan mengaplikasikan ilmu yang diperoleh dari perguruan tinggi untuk dapat diterapkan di masyarakat. Pelaksanaan kegiatan ini selain sebagai sarana pengabdian kepada masyarakat, bagian dari tri dharma perguruan tinggi, diharapkan juga dapat mengembangkan kemampuan praktis mahasiswa dalam menyalurkan keahlian yang dimiliki untuk diberikan kepada masyarakat, sehingga diharapkan mampu membantu menyelesaikan masalah yang ada di masyarakat dengan mengoptimalkan sumber daya yang ada.

Melalui kegiatan Pengabdian Kepada Masyarakat, mahasiswa diajak untuk merumuskan masalah yang kompleks, menelaah potensi-potensi dan kelemahan dalam masyarakat dan merumuskan sebuah program kegiatan yang dapat memberikan manfaat kepada masyarakat. Oleh karena itu, diharapkan melalui kegiatan PKM ini dapat menjamin adanya keterkaitan antara dunia akademik-teoritik dan dunia empiris-praktis, dengan demikian akan terjadi interaksi sinergis, saling menerima dan memberi, saling asah, asih dan asuh antara mahasiswa dan masyarakat.

Tempat pelaksanaan kegiatan PKM ini dilakukan didaerah Kelurahan Klandasan Ilir, yang masih termasuk dalam wilayah Kecamatan Balikpapan Kota. Waktu pelaksanaan kegiatan mulai tanggal 1 - 28 Februari 2018. Pelaksanaan PKM ini dengan menggunakan beberapa metode pelaksanaanya, diantaranya adalah:

1. Melakukan koordinasi dengan pihak kelurahan dan LPM Klandasan Ilir, untuk melakukan identifikasi permasalahan yang terkait dengan pelaksanaan PKM.

2. Membuat perencanaan program kerja yang akan dilakukan, dengan memperhatikan potensi dan sumber daya yang dimiliki warga Kelurahan Klandasan ilir.

3. Melaksanakan kegiatan yang telah direncanakan sesuai jadwal yang telah ditetapkan.

4. Mengevaluasi pelaksanaan kegiatan yang dilakukan dengan cara melakukan rapat koordinasi dan evaluasi dengan pihak Kelurahan dan LPM Klandasan Ilir untuk kegiatan yang telah dilaksanakan.

\section{HASIL DAN PEMBAHASAN}

Kegiatan PKM yang dilakukan di Kelurahan Klandasan Ilir ini adalah sebagai salah satu usaha untuk menyebarluaskan ilmu pengetahuan, informasi dan contoh kepada masyarakat. Pelaksanaan kegiatan PKM dimulai tanggal 1 - 28 Februari 2018. Adapun kegiatan yang telah dilakukan dalam program sosialisasi ini meliputi: 
1. Kerja bakti dilaksanakan di RT 32,50 dan 30 bersama warga setempat, seperti telihat di Gambar 1. Target kegiatan kerja bakti telah tercapai, karena berhasil menggerakkan warga setempat untuk berpartisipasi membersihkan lingkungan setempat, dan lingkungan menjadi lebih bersih. Selain itu, dapat melibatkan pihak dari kecamatan untuk bersama-sama membersihkan pesisir pantai Monpera. Pembuatan tong sampah dibeberapa RT di Kelurahan Klandasan Ilir. Indikator keberhasilan dari kegiatan ini adalah lingkungan menjadi lebih bersih, nyaman dan enak dilihat. Kegiatan yang dilakukan secara bersama-sama dengan warga ini diharapkan mampu menumbuhkan kesadaran masyarakat akan pentingnya kebersihan lingkungan.

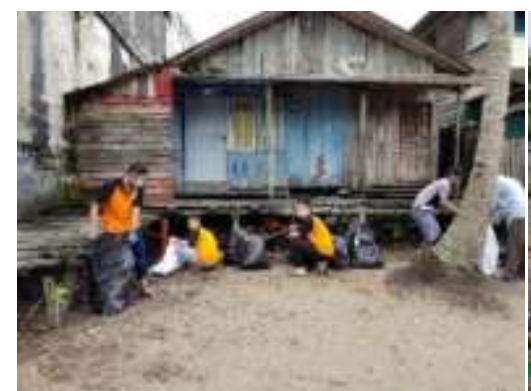

(a)

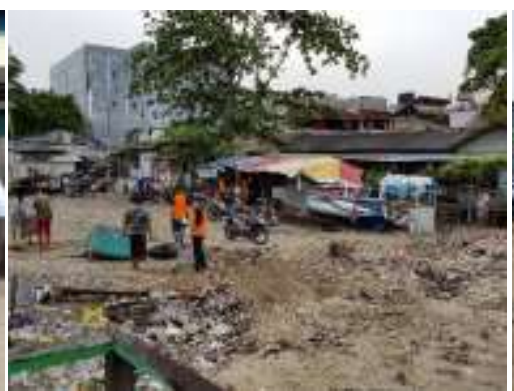

(b)

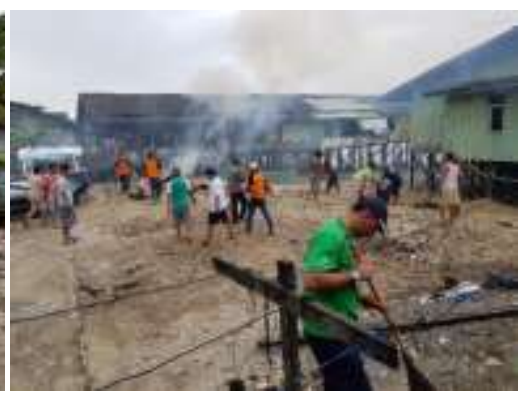

(c)

Gambar 1. Pelaksanaan kerja bakti melibatkan partisipasi aktif warga RT 50 (a) bersama warga RT 30 (b) dan RT 32 Kelurahan Klandasan Ilir, yang tinggal dikawasan dekat pesisir pantai (c)

2. Selain itu, aksi bersih-bersih pantai juga dilaksanakan dalam kegiatan PKM ini dengan melibatkan warga sekitar, Kelurahan dan LPM Klandasan Ilir. Indikator dari kegiatan ini diharapkan masyarakat yang tinggal dipesisir pantai mendapatkan pemahaman mengenai bahaya sampah plastik dan pentingnya menjaga kebersihan pantai dengan diikuti dengan aksi nyata, yang tidak sekedar teori semata. Selain itu, untuk menjamin keamanan warga, terutama anak-anak yang bermain disekitar pantai, dibuatkan pagar kayu tambahan untuk warga yang tinggal dipesisir. Papan peringatan untuk tidak membuang sampah ke laut juga dibuatkan dibeberapa area strategis, untuk selalu mengingatkan warga untuk tidak membuang sampah ke laut. Detail pelaksanaan kegiatan dapat dilihat pada gambar 2 berikut.

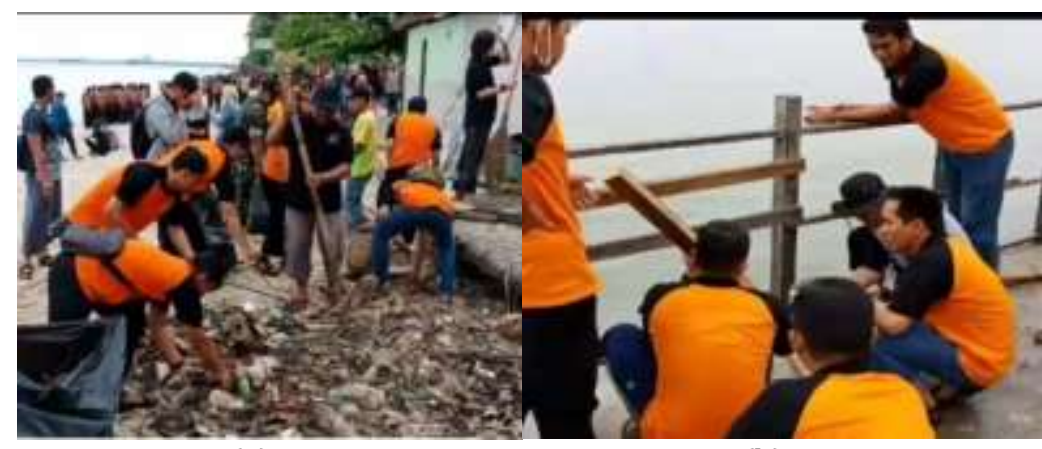

(a) (b)

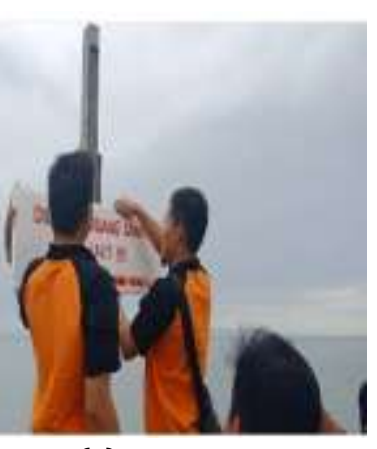

(c)

Gambar 2. Aksi bersih pantai dilakukan bersama warga (a), memasang pagar kayu pembatas untuk keamanan warga yang tinggal dikawasan dekat pantai (b), memasang papan dilarang membuang sampah ke laut (c)

3. Penanaman bibit pohon turi, bunga melati dan buah tin, sebanyak 94 bibit pohon. Indikator keberhasilan dari kegiatan ini adalah masyarakat ikut dilibatkan bagaimana persiapan tunas pohon turi dan bibit buah tin dan bunga melati yang akan ditanam disekitar pemukiman warga, seperti diapat dilihat pada gambar 3. Sehingga nantinya diharapkan, Ketika tanaman ini telah tumbuh dengan baik, akan membuat lingkungan menjadi lebih asri, sejuk, dan warga bisa mendapat manfaat dari jenis tanaman turi, bunga melati dan buah tin yang ditanam. 


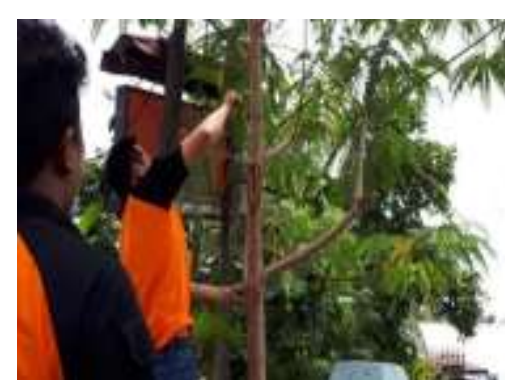

(a)

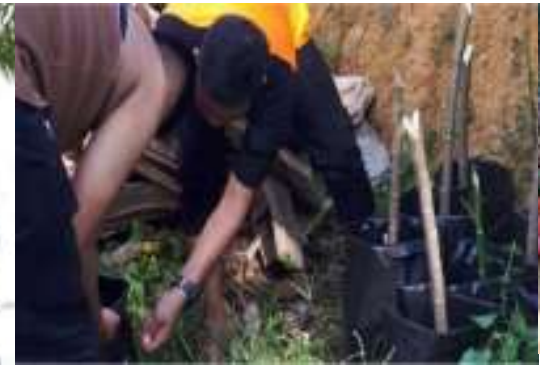

(b)

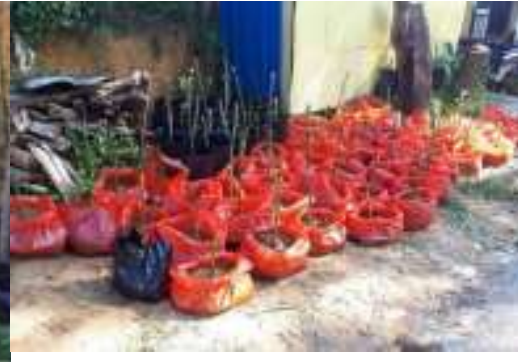

(c)

Gambar 3. Kegiatan penyiapan tunas pohon turi (a), tunas pohon turi dimasukkan dalam polybag (b), dan bibit pohon turi (sesbania grandiflora) yang sudah siap ditanam (c)

4. Pemberian materi kepada warga masyarakat di RT 32 dan sekitarnya, mengenai bagaimana cara pengelolaan dan penanganan minyak jelantah yang dihasilkan warga. Materi soslialisasi yang diberikan mencakup: a) bahaya penggunaan kembali minyak goreng bekas pakai bagi kesehatan, b) bahaya pembuangan limbah minyak goreng bekas pakai secara sembarangan, dan c) menjelaskan beberapa manfaat dari pengolahan kembali limbah minyak goreng bekas pakai. Sosialisasi ini diberikan pada warga agar mengetahui bagaimana langkah dalam penanganan minyak goreng bekas pakai. Sosialisasi ini merupakan salah satu alternatif solusi terhadap pengelolaan minyak goreng bekas pakai yang masih belum optimal. Indikator keberhasilan dari kegiatan ini adalah, jumlah warga yang hadir sekitar 80 orang, yang mengikuti pelaksanaan sosialisasi ini hingga akhir dengan sangat antusias. Hal ini terbukti dengan proses diskusi, pertanyaan yang diajukan warga dan penjelasan dari narasumber salah seorang penggagas Komunitas Jelantah 4 Change, Balikpapan, yang dalam hal ini diwakili oleh Bapak Johanes Anton. Detail pelaksanaan kegiatan dapat dilihat pada gambar 4 berikut.

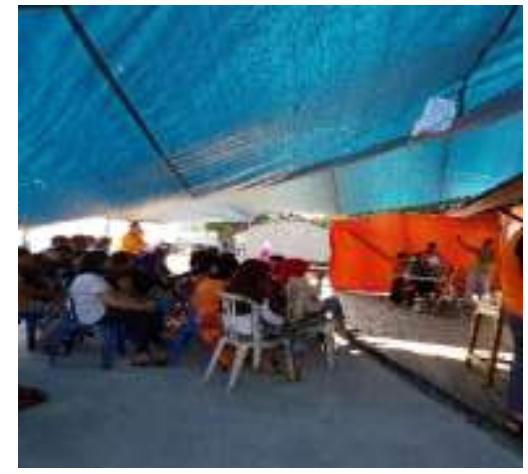

(a)

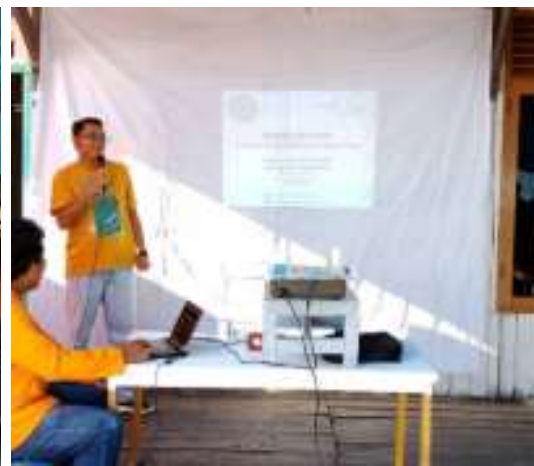

(b)

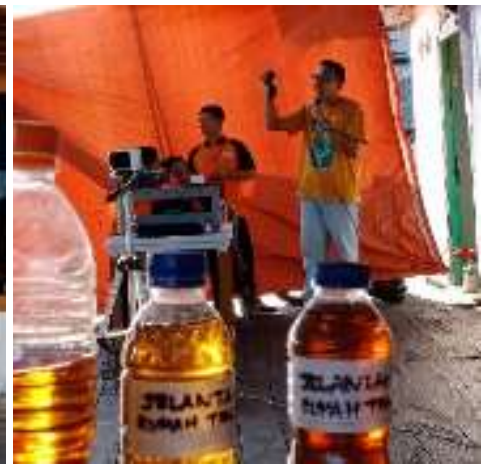

(c)

Gambar 4. Kegiatan sosialisasi pengelolaan minyak jelantah bersama bersama warga Kelurahan Klandasan Ilir (a), narasumber dari Komunitas Jelantah 4 Change Balikpapan (b), contoh-contoh minyak jelantah yang dihasilkan rumah tangga (c)

Adapun beberapa hasil evaluasi dari kegiatan PKM ini adalah : 1) kurang maksimalnya pengambilan data fasilitas umum karena keterbatasan waktu, informasi yang didapat dari warga karena kurang keterbukaan dalam memberikan informasi, rasa sungkan, segan untuk menceritakan kondisi aktual dilapangan. 2) Kendala yang kami dapatkan dari kegiatan pembuatan bibit pohon turi adalah keterbatasan polybag sebagai media tanam bibit turi. Selain itu, program kerja penanaman buah tin, bunga melati dan pohon turi tidak sesuai dengan target yang diharapkan, mengingat keterbatasan dana. Proposal pengadaan dana yang diajukan ke beberapa perusahaan di sekitar Kelurahan Klandasan Ilir tidak mendapatkan tanggapan dari 
beberapa instansi dan kegiatan usaha tersebut. 3) Kendala yang dihadapi dalam pelaksanaan sosialisasi adalah adanya kesulitan dalam menentukan waktu pelaksanaan kegiatan, dikarenakan masyarakat yang menjadi mitra pelaksanaan pengabdian ini memiliki kesibukan dalam menyelesaikan pekerjan rutinnya setiap harinya. Tim pengabdian dan masyarakat harus membuat kesepakatan waktu pelaksanaan kegiatan dengan cermat agar waktu pelaksanaan kegiatan pengabdian tidak berbenturan juga dengan waktu perkuliahan di Universitas Balikpapan. 4) Selain itu, target kegiatan sosialisasi yang dilakukan, tidak tercapai, karena dari 3 undangan warga RT yang diharapkan kehadirannya (RT 29, 30,32) hanya warga dari RT 32 saja yang hadir sedangkan perwakilan 2 RT lainnya berhalangan hadir. Kegiatan sosialisasi seperti ini perlu dilakukan secara berkelanjutan agar program berjalan sesuai dengan harapan dan tujuan. Pengelolaan sampah secara terpadu ataupun mandiri berbasis masyarakat tidak dapat diwujudkan dengan hanya sekedar memberikan sosialisasi atau dengan penyuluhan singat yang dilaksanakan hanya satu kali saja (Muryani et al., 2020). Harus ada sekelompok orang/komunitas yang mau bergerak dan memberikan contoh terlebih dahulu kepada warga disekitarnya, dan memberikan pendampingan secara menyeluruh (Raksun \& Karnan, 2019).

\section{KESIMPULAN}

Kesimpulan yang dapat diambil dari pelaksanaan kegiatan pengabdian kepada masyarakat di Kelurahan Klandasan Ilir ini, program kerja dapat terlaksana dengan baik dan masyarakatnya sangat kooperatif. Adanya kerja sama antar anggota tim dan pihak kelurahan Klandasan Ilir yang sangat baik dalam pelaksanaan program, serta dukungan dari ketua LPM dan RT dari Kelurahan Klandasan Ilir yang senantiasa memberi masukan dan dukungan terhadap terlaksanakannya program ini.

Masyarakat kelurahan Klandasan Ilir juga sangat mendukung adanya program PKM yang dijalankan di daerah sekitar tempat tinggalnya. Rasa ingin menambah pengetahuan yang besar dari masyarakat Kelurahan Klandasan Ilir serta kepedulian warga terhadap lingkungan dapat terlihat dengan upaya dan kesungguhan mereka mengikuti kegiatan pengabdian kepada masyarakat yang dilakukan di sekitar tempat tinggal warga. Kegiatan PKM di Kelurahan Klandasan Ilir mendapat sambutan yang baik dari masyarakat setempat, terlihat juga dari dukungan moril maupun materi demi kelancaran pelaksanaan kegiatan PKM ini. Perubahan gaya hidup untuk selalu menjaga kebersihan lingkungan harus terus selalu ditumbuhkan agar kepedulian masyarakat, terutama bagi mereka yang tinggal dipesisir pantai, agar tidak membuang sampah secara sembarangan yang dapat menimbulkan pencemaran ke laut.

\section{DAFTAR PUSTAKA}

Dan, P., Perempuan, P., Margasari, D., Wardany, K., Sari, R. P., \& Mariana, E. (2020). Sosialisasi Pendirian "Bank Sampah " Bagi Peningkatan. Dinamisia: Jurnal Pengabdian Kepada Masyarakat, 4(No 2), 364-372.

Greenpeace Indonesia (2019). Krisis Belum Terurai. Laporan Greenpeace Indonesia 12 November 2019, dari https://www.greenpeace.org/indonesia/laporan/

Harisman, K., Frasetya, B., Sudrajat, A., Birnadi, S., \& Sholeha, M. (2019). Penanaman Pohon Sebagai Upaya Menjaga Cadangan Air. Al-Khidmat, 2(1), 35-39.

Hidayat, M. T. (2017). Penanggulangan Pencemaran Pesisir Di Desa Tamberu Untuk Peningkatan Pelestarian Ekosistem Laut. In Seminar Nasional Hasil Pengabdian Kepada Masyarakat, 1, 255259.

Izza M Apriliani, Noir P Purba, Lantun P Dewanti, Heti Herawati, D. I. F. (2017). Aksi Besih Pantai Rangka Penanggulangan Pencemaran Pesisir di Pantai Pangandaran. Pengabdian Kepada Masyarakat, 1(No 2), 77-80. https://doi.org/10.1017/CB09781107415324.004

Kataren, S. (2005). Pengantar Teknologi Minyak dan Lemak Pangan. Jakarta: Universitas Indonesia

Linarti, U., Astuti, A. Y., \& Budiarti, G. I. (2019). Pengelolaan limbah minyak goreng bekas pakai di 
bank sampah Lintas Winongo, Kelurahan Bumijo, Kecamatan Jetis, Kota Yogyakarta. Seminar Nasional, Hasil Pengabdian Kepada Masyarakat Universitas Ahmad Dahlan, (September), 513520.

Mayangsari, M., Nurhayati, Junaenah, \& Kurniasih, N. (2020). Penyuluhan Mengenai Konsep Zero Waste Dan Pentingnya Pengelolaan Sampah Mandiri Bagi Masyarakat Di Kompleks Mabad 65 Rempoa Ciputat Tangerang Selatan. Abdi Laksana Jurnal Pengabdian Kepada Masyarakat, 1(1), 76-83.

Muryani, E., Widiarti, I. W., Savitri, N. D., Muryani, E., Widiarti, I. W., \& Savitri, N. D. (2020). Pembentukan Komunitas Pengelola Sampah Terpadu Berbasis Masyrakat. Pengabdian Dan Pemberdayaan Masyarakat JPPM LPIP UMP, 4(No 1).

Pratiwi, D. A. (2017). Pemberdayaan Masyarakat Rw 12 Dalam Kegiatan Penghijauan Lingkungan Di Kavling Mandiri Kelurahan Sei Pelunggut. Minda Baharu, 1(1), 25-32. https://doi.org/10.33373/jmb.v1i1.1170

Raksun, A., \& Karnan, K. (2019). Pembinaan Masyarakat dalam Budidaya Tanaman Cabai Rawit dengan Sistem Bedengan Lahan dan Aplikasi Mulsa Plastik. Jurnal Pengabdian Magister Pendidikan IPA, 1(2), 1-7. https://doi.org/10.29303/jpmpi.v1i2.240

Rukmini, A. (2007). Komparasi Efektifitas Adsorben Komeersial dan Non Komersial Dalam Proses Regenerasi Minyak Jelantah. Prosiding Seminar Nasional Teknologi Pangan (pp. 455-459). Semarang: Universitas Widya Mataram.

Sari, M., Lestari, S. U., \& Awal, R. (2018). Peningkatan Ketrampilan Mahasiswa Dalam Pengelolaan Sampah Organik Untuk Mewujudkan Green Campus Di Universitas Lancang Kuning. Dinamisia: Jurnal Pengabdian Kepada Masyarakat, 2(2), 193-196. https://doi.org/10.31849/dinamisia.v2i2.1392

Simanjuntak, F. N., Sanga, L., Purba, L., \& Irawati, N. (2019). Peningkatan Pengetahuan Kimia dalam Kehidupan Sehari-hari pada Ibu Rumah Tangga Perkotaan Kelas Ekonomi Menengah. Jurnal Comunita Servizio, 1(No 2), 98-108.

Siswati, L., Nizar, R., Ariyanto, A., Agribisnis, S., Pertanian, F., \& Kuning, U. L. (2020). Pengolahan Sampah Rumah Tangga Menjadi Kompos di Kelurahan Tuah Madani Kecamatan Tampan Kota Pekanbaru. Dinamisia : Jurnal Pengabdian Kepada Masyarakat, 4(3), 519-524.

Sukib, S., Muti'ah, M., Siahaan, J., \& Supriadi, S. (2020). Meningkatkan Kesadaran Bahaya Sampah Laut Melalui Pendampingan pada Masyarakat Lokasi Wisata Pantai Kuranji. Jurnal Pengabdian Magister Pendidikan IPA, 2(2). https://doi.org/10.29303/jpmpi.v2i2.343

Suryani, L., Aje, A. U., \& Tute, K. j. (2019). Pkm Pelatihan Kelompok Anak Cinta Lingkungan Kabupaten Ende Dalam Pegelolaan Limbah Organik Dan Anorganik Berbasis 3R Untuk Mengeskalasi Nilai Ekonomis Barang Sebagai Bekal Wirausaha Mandiri. Dinamisia: Jurnal $\begin{array}{llll}\text { Pengabdian Kepada } & \text { Masyarakat, 244-251. }\end{array}$ https://doi.org/10.31849/dinamisia.v3i2.3679

Vamala, M. A., Akbar, I. M., Widayanti, B. H., Lingkungan, S. R., \& Jelantah, M. (2019). Pendampingan pengolahan minyak jelantah dan limbah buah sebagai sabun ramah lingkungan *. Jurnal SINERGI : Pengabdian UMMAT, 1(No 2), 32-36. 